\title{
Reducing Fungal Exposure Critical for Treating Rhinosinusitis with or without Polyps [Response to Letter]
}

\author{
Claus Bachert ${ }^{1,2}$ \\ Neil Bhattacharyya ${ }^{3}$ \\ Martin Desrosiers ${ }^{4}$ \\ Asif $\mathrm{H}$ Khan ${ }^{1,5}$ \\ 'Upper Airways Research Laboratory, \\ Department of Otorhinolaryngology, \\ Ghent University, Ghent, Belgium; \\ ${ }^{2}$ CLINTEC, Karolinska Institutet, \\ Stockholm, Sweden; ${ }^{3}$ Department of \\ Otolaryngology, Harvard Medical School, \\ Boston, MA, USA; ${ }^{4}$ Centre De \\ Recherche Du Centre Hospitalier De \\ I'Université De Montréal (CRCHUM), \\ Montreal, QC, Canada; ${ }^{5}$ Sanofi, Chilly- \\ Mazarin, France
}

\section{Dear editor}

We thank Dr Curtis for his interest in our article, ${ }^{1}$ and welcome the opportunity to address the putative role of molds and fungi in chronic rhinosinusitis (CRS).

The potential contribution of fungi to the pathophysiology of CRS has been a focus of investigation many years back, and showed strong variation depending on the environment and climate. ${ }^{2,3}$ The emerging understanding that the nose and sinuses naturally host a microbiome including viruses, bacteria, and fungi, suggests that the presence of microorganisms is itself not a key etiological factor in CRS. ${ }^{4}$ Moreover, there is a lack of convincing immunological data to link fungi to the disease process in the great majority of CRS cases. ${ }^{5}$ Consistent with this understanding, a 2018 Cochrane Review found no good evidence that oral or topical antifungals have a positive effect of quality of life, symptoms, or signs of disease in patients with CRS. ${ }^{6}$ Indeed, consensus guidelines advise against the use of antifungals in CRS. ${ }^{4}$

Among the phenotypes of CRS, allergic fungal rhinosinusitis (AFRS) is recognized as distinct from CRS with nasal polyps (CRSwNP), which was the subject of our review, in its diagnosis, presentation, clinical course, pathophysiology, and management. ${ }^{4,7,8}$ AFRS is a chronic disease that occurs predominantly in warm, humid climates and is characterized by a robust type 2 inflammatory response directed against colonizing fungi with accumulation of eosinophilic mucin containing fungal hyphae leading to persistent sinus opacification and nasal polyp formation. However, there is good evidence that AFRS accounts for only approximately $5-10 \%$ of CRS cases. ${ }^{4,9-12}$ The study referenced in Dr Curtis' letter, which reported presence of AFRS in 94 of 101 CRS surgical patients, investigated a heterogenous population of patients with CRSwNP as well as CRS without nasal polyps diagnosed by recurrent upper tract infections lasting longer than 3 months and inflammatory mucosal thickening, ${ }^{13}$ which is not consistent with the current diagnostic criteria for $\mathrm{CRSwNP}^{4}$ and reported a large heterogeneity in polyp size from "minimal" to "massive". The contribution of fungi to CRS in this study is particularly unclear since $100 \%$ of the control population were reported as culture-positive for fungi, with a microbiome profile similar to that of CRS patients.

While the potential association between CRS, including AFRS, and exposure to mold is an area of investigation, a causal relationship has never been demonstrated. A reduction in rhinosinusitis symptoms following reduction in allergen exposure is not surprising in patients with CRS and allergic rhinitis. However, a recent analysis of home mold
Correspondence: Claus Bachert Email claus.bachert@ugent.be 
exposure found no difference in exposure levels between patients with AFRS and controls with atopic CRSwNP, which suggests that mold exposure levels may not be a key driver in development of AFRS. ${ }^{14}$

In summary, the absence of convincing evidence after more than two decades of investigation suggests that the hypothesis of fungi playing a major role in the pathophysiology of CRS in general has not been accepted; future research may identify genetic traits, or its interplay with environmental factors in CRSwNP disease evolution.

\section{Funding}

Medical writing/editorial assistance was provided by Matt Lewis, $\mathrm{PhD}$ of Adelphi Group, Macclesfield, UK, in accordance with Good Publication Practice (GPP3) guidelines and funded by Sanofi Genzyme and Regeneron Pharmaceuticals, Inc.

\section{Disclosure}

Professor Claus Bachert reports personal fees from and is Principal Investigator of study and advisory board for GSK, Principal Investigator of studies for AstraZeneca and Sanofi, consulting for Mylan, consulting and presentations for ALK, outside the submitted work; and is an advisory board member of ALK, AstraZeneca, GlaxoSmithKline, Novartis, and Sanofi.

Dr Neil Bhattacharyya reports personal fees from Sanofi outside the submitted work and is a consultant for Sanofi.

Dr Martin Desrosiers reports personal fees from GlaxoSmithKline, grants from Sanofi and Regeneron, advisory board, speaker bureau, and clinical investigator for GlaxoSmithKline, Sanofi and Regeneron, and AstraZeneca, during the conduct of the study; is a major equity holder of Probionase Therapies outside the submitted work; has received clinical trial funding from AstraZeneca, GlaxoSmithKline, Probionase Therapies, and Sanofi; and is an advisory board member of Regeneron Pharmaceuticals, Inc. and Sanofi.

Dr Asif H Khan reports being an employee of Sanofi, during the conduct of the study and may hold stock and/or stock options.

\section{References}

1. Bachert C, Bhattacharyya N, Desrosiers M, Khan AH. Burden of disease in chronic rhinosinusitis with nasal polyps. $J$ Asthma Allergy. 2021;14:127-134. doi:10.2147/JAA.S290424

2. Orlandi RR, Marple BF. The role of fungus in chronic rhinosinusitis. Otolaryngol Clin North Am. 2010;43(3):531-537. doi:10.1016/j. otc. 2010.02 .011

3. Fokkens WJ, Ebbens F, van Drunen CM. Fungus: a role in pathophysiology of chronic rhinosinusitis, disease modifier, a treatment target, or no role at all? Immunol Allergy Clin North Am. 2009;29 (4):677-688. doi:10.1016/j.iac.2009.07.002

4. Fokkens WJ, Lund VJ, Hopkins C, et al. European position paper on rhinosinusitis and nasal polyps 2020. Rhinology. 2020;58(Suppl S29):1-464. doi:10.4193/Rhin20.401

5. Ebbens FA, Georgalas C, Fokkens WJ. Fungus as the cause of chronic rhinosinusitis: the case remains unproven. Curr Opin Otolaryngol Head Neck Surg. 2009;17(1):43-49. doi:10.1097/ MOO.0b013e32831de91e

6. Head K, Sharp S, Chong LY, Hopkins C, Philpott C. Topical and systemic antifungal therapy for chronic rhinosinusitis. Cochrane Database Syst Rev. 2018;9:CD012453.

7. Glass D, Amedee RG. Allergic fungal rhinosinusitis: a review. Ochsner J. 2011;11(3):271-275.

8. Tyler MA, Luong AU. Current understanding of allergic fungal rhinosinusitis. World J Otorhinolaryngol Head Neck Surg. 2018;4 (3):179-185. doi:10.1016/j.wjorl.2018.08.003

9. Alshaikh NA, Alshiha KS, Yeak S, Lo S. Fungal rhinosinusitis: prevalence and spectrum in Singapore. Cureus. 2020;12(4):e7587. doi: $10.7759 /$ cureus. 7587

10. Bakhshaee M, Fereidouni M, Mohajer MN, Majidi MR, Azad FJ, Moghiman T. The prevalence of allergic fungal rhinosinusitis in sinonasal polyposis. Eur Arch Otorhinolaryngol. 2013;270 (12):3095-3098. doi:10.1007/s00405-013-2449-5

11. Telmesani LM. Prevalence of allergic fungal sinusitis among patients with nasal polyps. Ann Saudi Med. 2009;29(3):212-214. doi:10.5144/ 0256-4947.2009.212

12. Philpott CM, Erskine S, Hopkins C, et al. Prevalence of asthma, aspirin sensitivity and allergy in chronic rhinosinusitis: data from the UK National Chronic Rhinosinusitis Epidemiology Study. Respir Res. 2018;19(1):129. doi:10.1186/s12931-018-0823-y

13. Ponikau JU, Sherris DA, Kern EB, et al. The diagnosis and incidence of allergic fungal sinusitis. Mayo Clin Proc. 1999;74(9):877-884. doi:10.4065/74.9.877

14. Rowan NR, Storck KA, Schlosser RJ, Soler ZM. The role of home fungal exposure in allergic fungal rhinosinusitis. Am J Rhinol Allergy. 2020;34(6):784-791. doi:10.1177/1945892420930953 
Dove Medical Press encourages responsible, free and frank academic debate. The content of the Journal of Asthma and Allergy 'letters to the editor' section does not necessarily represent the views of Dove Medical Press, its officers, agents, employees, related entities or the Journal of Asthma and Allergy editors. While all reasonable steps have been taken to confirm the content of each letter, Dove Medical Press accepts no liability in respect of the content of any letter, nor is it responsible for the content and accuracy of any letter to the editor.

Journal of Asthma and Allergy

Dovepress

\section{Publish your work in this journal}

The Journal of Asthma and Allergy is an international, peer-reviewed open-access journal publishing original research, reports, editorials and commentaries on the following topics: Asthma; Pulmonary physiology; Asthma related clinical health; Clinical immunology and the immunological basis of disease; Pharmacological interventions and new therapies. The manuscript management system is completely online and includes a very quick and fair peer-review system, which is all easy to use. Visit http://www.dovepress.com/testimonials.php to read real quotes from published authors.

Submit your manuscript here: https://www.dovepress.com/journal-of-asthma-and-allergy-journal 